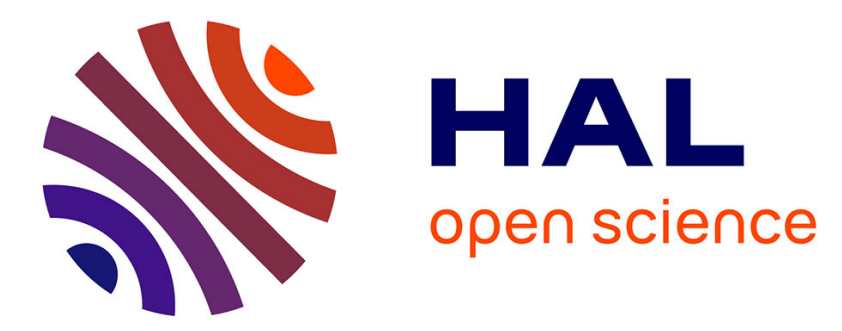

\title{
Stress Corrosion Cracking Sensitivity of High Purity Fe-Cr Alloys in High Temperature Water
}

\author{
H. Takaku, S. Kato, J. Tani, K. Abiko
}

\section{To cite this version:}

H. Takaku, S. Kato, J. Tani, K. Abiko. Stress Corrosion Cracking Sensitivity of High Purity Fe-Cr Alloys in High Temperature Water. Journal de Physique IV Proceedings, 1995, 05 (C7), pp.C7-397C7-402. 10.1051/jp4:1995748 . jpa-00254043

\section{HAL Id: jpa-00254043 https://hal.science/jpa-00254043}

Submitted on 1 Jan 1995

HAL is a multi-disciplinary open access archive for the deposit and dissemination of scientific research documents, whether they are published or not. The documents may come from teaching and research institutions in France or abroad, or from public or private research centers.
L'archive ouverte pluridisciplinaire HAL, est destinée au dépôt et à la diffusion de documents scientifiques de niveau recherche, publiés ou non, émanant des établissements d'enseignement et de recherche français ou étrangers, des laboratoires publics ou privés. 


\title{
Stress Corrosion Cracking Sensitivity of High Purity Fe-Cr Alloys in High Temperature Water
}

\author{
H. Takaku, S. Kato, J. Tani and K. Abiko* \\ Komae Research Laboratory, CRIEPI, Komae, Tokyo 201, Japan \\ * Institute for Materials Research, Tohoku University, Sendai 980-77, Japan
}

\begin{abstract}
Stress Corrosion Cracking (SCC) sensitivities of high purity $\mathrm{Fe}-\mathrm{Cr}$ alloys were investigated in simulated Boiling Water Reactor (BWR) and primary Pressurized Water Reactor (PWR) cooling waters, by constant extension rate tests (CERT) at a strain rate of $4 \times 10^{-7} \mathrm{~s}^{-1}$.

No high purity $\mathrm{Fe}-\mathrm{Cr}$ alloy showed any SCC sensitivity in either simulated BWR and PWR primary water environment.
\end{abstract}

\section{INTRODUCTION}

Stainless Steels are widely used for structural materials such as piping and equipment in nuclear and fossil fuel power plants. In particular, high corrosion resistance in high-temperature cooling water is required as one of the most important material characteristics.

Generally, stress corrosion cracking (SCC) is considered to occur in cases when the three factors comprising material, stress and environment interact with one another [1,2]. The authors studied the SCC behaviour of materials in simulated nuclear and fossil cooling water environments [3-7]. Dynamic strain enhances SCC sensitivity in corrosive environments due to the mechano-chemical effects $[8,9]$.

The Japan Research Association on Ultra High Purity Materials has promoted collaborative study of high purity $\mathrm{Fe}-\mathrm{Cr}$ alloys as one of its research activities [10].

In the present work, the SCC sensitivity behaviour of high purity $\mathrm{Fe}-\mathrm{Cr}$ alloys were investigated in the simulated BWR and PWR primary cooling waters, as compared with those of one intermediate purity $\mathrm{Fe}-\mathrm{Cr}$ alloy and commercial-base type 430 and 304 stainless steels.

\section{EXPERIMENTAL PROCEDURE}

\subsection{Materials}

The chemical composition of specimens for tests is shown in Table 1. Four kinds of high purity $\mathrm{Fe}-\mathrm{Cr}$ alloys with $\mathrm{Cr}$ contents of $16,25,35$ and $50 \mathrm{wt} \%$ from high purity electrolytic iron and chromium, an intermediate purity $\mathrm{Fe}-30 \mathrm{wt} \% \mathrm{Cr}$, and commercial base type 430 and 304 stainless steels were used for the tests.

\begin{tabular}{|l||c|c|c|c|c|c|c|c|c|c|}
\hline Material & $\mathrm{Cr}$ & $\mathrm{Ni}$ & $\mathrm{C}$ & $\mathrm{S}$ & $\mathrm{O}$ & $\mathrm{N}$ & $\mathrm{Mn}$ & $\mathrm{Si}$ & $\mathrm{Al}$ & $\mathrm{P}$ \\
\hline \hline $\mathrm{Fe}-16 \mathrm{Cr}$ & $\mathbf{1 6}$ & $\mathrm{na}$ & 0.0005 & 0.0001 & 0.0076 & 0.0006 & na & na & na & na \\
\hline $\mathrm{Fe}-25 \mathrm{Cr}$ & 25 & na & 0.0006 & 0.0002 & 0.0070 & 0.0008 & na & na & na & na \\
\hline Fe-35Cr & $\mathbf{3 5}$ & na & 0.0008 & $\mathbf{0 . 0 0 0 4}$ & 0.0081 & 0.0009 & na & na & na & na \\
\hline Fe-50Cr & 50 & na & $\mathbf{0 . 0 0 0 9}$ & 0.0005 & 0.0070 & $\mathbf{0 . 0 0 1 1}$ & na & na & na & na \\
\hline \hline Fe-30Cr & 30 & na & 0.012 & 0.0006 & 0.0084 & $\mathbf{0 . 0 0 8 4}$ & $\mathbf{0 . 1 0}$ & $\mathbf{0 . 1 1}$ & $\mathbf{0 . 0 3 6}$ & $\mathbf{0 . 0 2 8}$ \\
\hline Type430 & $\mathbf{1 6 . 1}$ & $\mathbf{0 . 1}$ & $\mathbf{0 . 0 6}$ & $\mathbf{0 . 0 0 1}$ & na & na & $\mathbf{0 . 1 4}$ & $\mathbf{0 . 5 0}$ & na & $\mathbf{0 . 0 1 6}$ \\
\hline Type304 & $\mathbf{1 8 . 5}$ & $\mathbf{9 . 4}$ & $\mathbf{0 . 0 7}$ & $\mathbf{0 . 0 0 1}$ & na & na & $\mathbf{1 . 5 0}$ & $\mathbf{0 . 5 0}$ & na & $\mathbf{0 . 0 0 2}$ \\
\hline
\end{tabular}

Table 1 Chemical composition of specimens (wt.\%) 


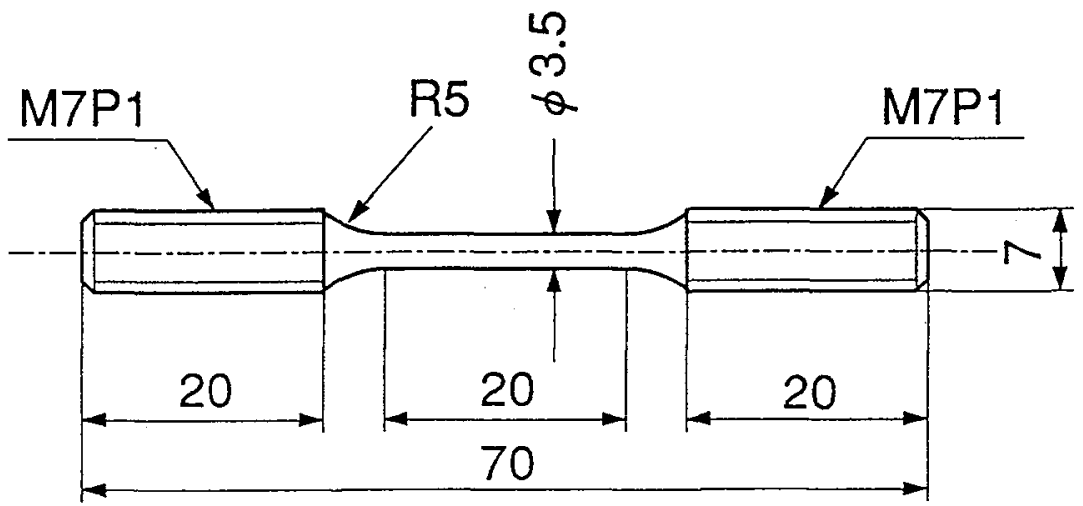

Fig.1 Specimen Size(in $\mathrm{mm}$ ) and Shape for Constant Extension Rate Test

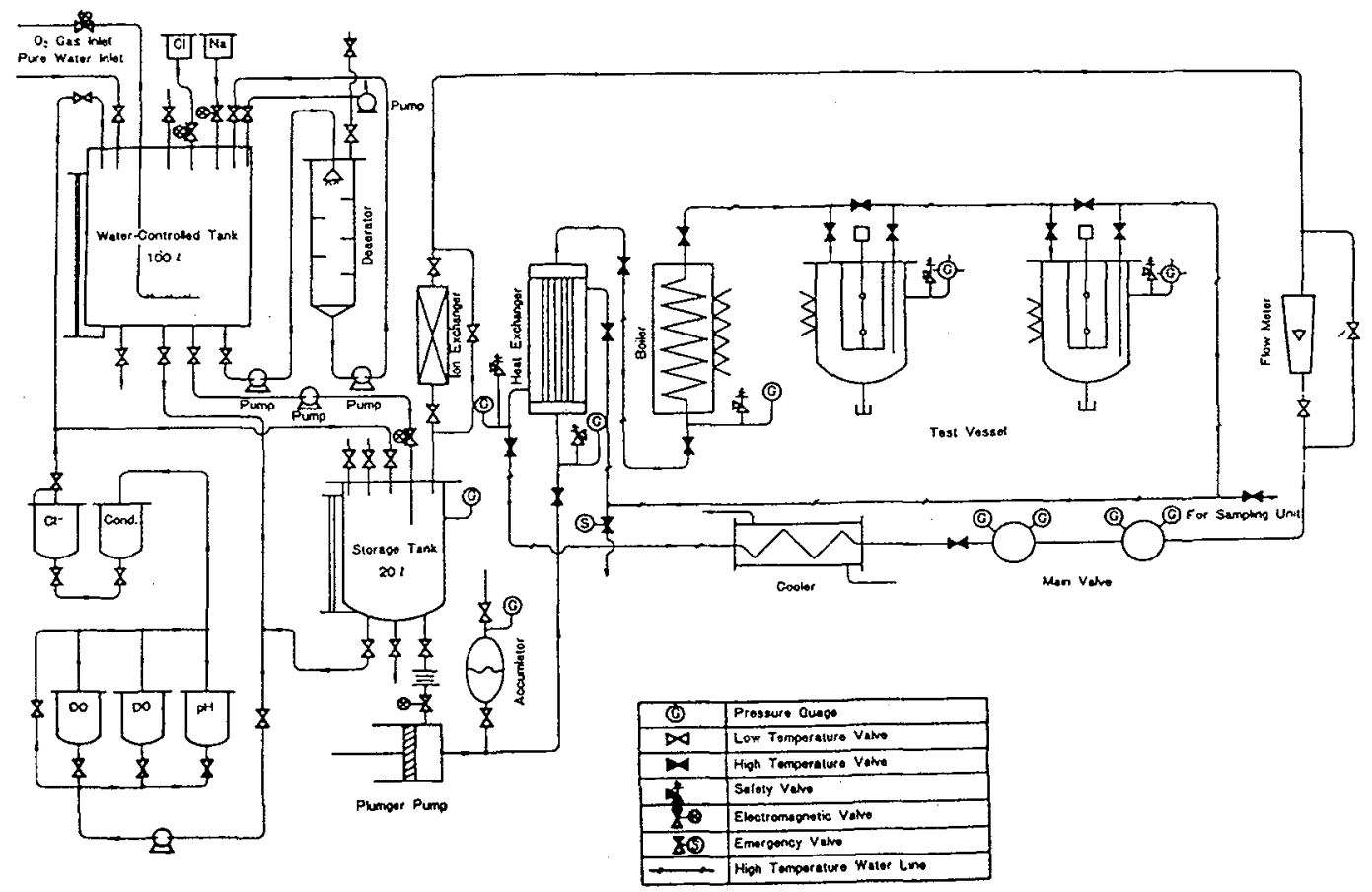

Fig.2 Flow Diagram of Stress Corrosion Test Facility 


\subsection{Test Specimens and Heat Treatment}

The size and shape of specimens for mechanical and stress corrosion cracking tests are shown in Fig.1.

Solution heat treatment of all the specimens was conducted by heating at $1000^{\circ} \mathrm{C}$ for $30 \mathrm{~min}$ and then cooling in ambient air. After this solution treatment, the specimens were subjected to sensitization heat treatment which is required for the simulated welding heats in power plant components and piping by heating at $650^{\circ} \mathrm{C}$ for $2 \mathrm{hr}$ and then cooling in air.

\subsection{SCC Test}

The SCC test was conducted in a recirculated-refreshed water loop shown in Fig. 2. For the simulated BWR environment, the high purity water at $288^{\circ} \mathrm{C}$ was supplied to the test vessels (autoclaves). The quality of water at the outlet of the autoclave is $\mathrm{pH} 6.7$, the electrical resistivity $0.6 \mu \mathrm{S} / \mathrm{cm}$ and the dissolved oxygen (DO) approximately 8ppm, controlled by flow of mixed $\mathrm{N}_{2}+\mathrm{O}_{2}$ gas. The DO concentration in the usual BWR feedwater is $0.2 \mathrm{ppm}(200 \mathrm{ppb})$ on average. The $8 \mathrm{ppm}$ DO concentration in this work was therefore increased during an environmentally-accelerated SCC test.

For the simulated PWR primary environment, water at $320^{\circ} \mathrm{C}$ containing about $500 \mathrm{ppm} \mathrm{B}\left(\mathrm{H}_{3} \mathrm{BO}_{3}\right)$, 2ppm $\mathrm{Li}(\mathrm{LiOH})$ and $30 \mathrm{cc} / \mathrm{H}_{2}$ was supplied to the autoclaves. The quality of water at the outlet of the autoclave was $\mathrm{pH} 6.9$, the electrical resistivity $21 \mu \mathrm{S} / \mathrm{cm}, 2.5 \mathrm{ppm} \mathrm{H}_{2}$ content and the dissolved oxygen content less than $5 \mathrm{ppb}$. This coolant environment of the present test was not accelerated for corrosion, as compared to the actual PWR primary water.

In the water environments above-mentioned, the constant extension rate test (CERT) / slow strain rate test (SSRT) was conducted at the strain rate of $4 \times 10^{-7} \mathrm{sec}^{-1}$ for the SCC evaluation.

\subsection{Tensile Test in a Non-corrosive Environment}

In order to compare the mechanical properties and fracture mode in water with those in non-corrosive environments, CERT/SSRT was also conducted in Ar gas, purity $99.99 \mathrm{vol} \%$. The tensile testing machine was the same one used in the SCC tests. The strain rate was also the same value of $4 \times 10^{-7} \mathrm{sec}^{-1}$ as for the SCC tests.

\subsection{Observation after Testing}

The fracture mode of the specimens after SCC and tensile tests was observed by SEM.

\section{RESULTS AND DISCUSSION}

\subsection{Mechanical Properties}

The results of the tensile tests, which were conducted in the non-corrosive pure Ar gas at $288^{\circ} \mathrm{C}$ and $320^{\circ} \mathrm{C}$, are summarized in Tables 2 and 3, respectively. At first, both $0.2 \%$ proof stress and the ultimate tensile strength of high purity $\mathrm{Fe}-\mathrm{Cr}$ alloys become high with $\mathrm{Cr}$ concentration, although those at different test temperatures were almost the same. This behaviour may be due to the solid solution hardening effects of the $\mathrm{Cr}$ atom. Total elongation of high purity $\mathrm{Fe}-\mathrm{Cr}$ alloys shows the behaviour under investigation. The $\mathrm{Fe}-$ $35 \mathrm{Cr}$ alloy has the largest elongation, and $\mathrm{Fe}-50 \mathrm{Cr}$ alloy has astonishingly high ductility.

On the other hand, the elongation of intermediate purity $\mathrm{Fe}-30 \mathrm{Cr}$ alloy is a little lower than that of high purity $\mathrm{Fe}-35 \mathrm{Cr}$ alloy.

\begin{tabular}{|c||c|c|c|}
\hline Material & $\begin{array}{c}0.2 \% \text { Proof Stress } \\
(\mathrm{MPa})\end{array}$ & $\begin{array}{c}\text { Ultimate Tensile } \\
\text { Stress (MPa) }\end{array}$ & $\begin{array}{c}\text { Total Elongation } \\
(\%)\end{array}$ \\
\hline \hline Fe-16Cr & 112 & 278 & 27.3 \\
\hline Fe-25Cr & 115 & 364 & 38.9 \\
\hline Fe-35Cr & 180 & 447 & 40.5 \\
\hline Fe-50Cr & 542 & 678 & 18.6 \\
\hline \hline Fe-30Cr & 182 & 448 & 34.2 \\
\hline Type430 & 336 & 510 & 14.7 \\
\hline Type304 & 164 & 521 & 54.2 \\
\hline
\end{tabular}

Table 2 Constant strain rate test results, at a strain rate of $4 \times 10^{-7} \mathrm{sec}^{-1}$ in $288^{\circ} \mathrm{C}$ pure $\mathrm{Ar}$ 


\begin{tabular}{|c||c|c|c|}
\hline Material & $\begin{array}{c}\text { 0.2\%Proof Stress } \\
(\mathrm{MPa})\end{array}$ & $\begin{array}{c}\text { Ultimate Tensile } \\
\text { Stress (MPa) }\end{array}$ & $\begin{array}{c}\text { Total Elongation } \\
(\%)\end{array}$ \\
\hline \hline Fe-16Cr & 134 & 276 & 29.9 \\
\hline Fe-35Cr & 174 & 436 & 38.3 \\
\hline Fe-50Cr & 519 & 661 & 17.5 \\
\hline Type430 & 219 & 462 & 20.0 \\
\hline Type304 & 182 & 534 & 50.5 \\
\hline
\end{tabular}

Table 3 Constant strain rate test results, at a strain rate of $4 \times 10^{-7} \mathrm{sec}^{-1}$ in pure Ar at $320^{\circ} \mathrm{C}$

As for the characteristics of the high purity $\mathrm{Fe}-16 \mathrm{Cr}$ alloy and the Type 430 ferritic stainless steel which have almost the same $\mathrm{Cr}$ content, the former material has higher elongation and lower strength than the latter. This mechanical behaviour of high purity $\mathrm{Fe}-16 \mathrm{Cr}$ alloy mainly results from the low content in interstitial elements such as carbon.

Detailed consideration and interpretation of the above-mentioned results will be clarified from the viewpoint of these microstructures and crystal structure in the near future.

The mechanical properties of commercial base Type 430 and 304 stainless steels show the usual behaviour in both strength and ductility.

\subsection{SCC Sensitivity}

The results of the SCC test in pure water at $288^{\circ} \mathrm{C}$ (simulated BWR coolant) and water at $320^{\circ} \mathrm{C}$ (simulated PWR primary coolant) are shown in Tables 4 and 5 , respectively. Stress-strain curves tested at $288^{\circ} \mathrm{C}$ in high purity Ar gas and in the simulated BWR are shown in Fig. 3 and 4, respectively.

\begin{tabular}{|c||c|c|c|c|}
\hline Material & $\begin{array}{c}\text { 0.2\%Proof } \\
\text { Stress (MPa) }\end{array}$ & $\begin{array}{c}\text { Ultimate Tensile } \\
\text { Stress (MPa) }\end{array}$ & $\begin{array}{c}\text { Total } \\
\text { Elongation } \\
(\%)\end{array}$ & $\begin{array}{c}\text { Stress Corrosion Cracking } \\
\text { Sensitivity }\end{array}$ \\
\hline \hline $\mathrm{Fe}-16 \mathrm{Cr}$ & 116 & 310 & 32.7 & Non \\
\hline $\mathrm{Fe}-25 \mathrm{Cr}$ & 129 & 373 & 36.1 & Non \\
\hline $\mathrm{Fe}-35 \mathrm{Cr}$ & 186 & 440 & 42.0 & Non \\
\hline $\mathrm{Fe}-50 \mathrm{Cr}$ & 506 & 629 & 18.6 & Non \\
\hline \hline $\mathrm{Fe}-30 \mathrm{Cr}$ & 187 & 456 & 31.5 & Non \\
\hline Type430 & 301 & 502 & 15.9 & IGSCC * \\
\hline Type304 & 167 & 388 & 17.4 & \\
\hline
\end{tabular}

IGSCC *: Intergranular Stress Corrosion Cracking

Table 4 Constant strain rate test results, at a strain rate of $4 \times 10^{-7} \mathrm{sec}^{-1}$ in pure water at $288^{\circ} \mathrm{C}$

\begin{tabular}{|c||c|c|c|c|}
\hline Material & $\begin{array}{c}0.2 \% \text { Proof } \\
\text { Stress (MPa) }\end{array}$ & $\begin{array}{c}\text { Ultimate Tensile } \\
\text { Stress (MPa) }\end{array}$ & $\begin{array}{c}\text { Total } \\
\text { Elongation } \\
(\%)\end{array}$ & $\begin{array}{c}\text { Stress Corrosion Cracking } \\
\text { Sensitivity }\end{array}$ \\
\hline \hline Fe-16Cr & 131 & 309 & 29.5 & Non \\
\hline Fe-35Cr & 191 & 451 & 44.1 & Non \\
\hline Fe-50Cr & 552 & 678 & 17.1 & Non \\
\hline \hline Type430 & 324 & 491 & 18.0 & Non \\
\hline Type304 & 200 & 560 & 52.0 & Non \\
\hline
\end{tabular}

Table 5 Constant strain rate test results, at a strain rate of $4 \times 10^{-7} \mathrm{sec}^{-1}$ in PWR primary water at $320^{\circ} \mathrm{C}$

Stress corrosion cracking occurred only for Type 304 stainless steel in the oxygenated water (simulated BWR coolant environment). No material and test environments except the Type 304 stainless steel in simulated BWR coolant showed SCC sensitivity. 


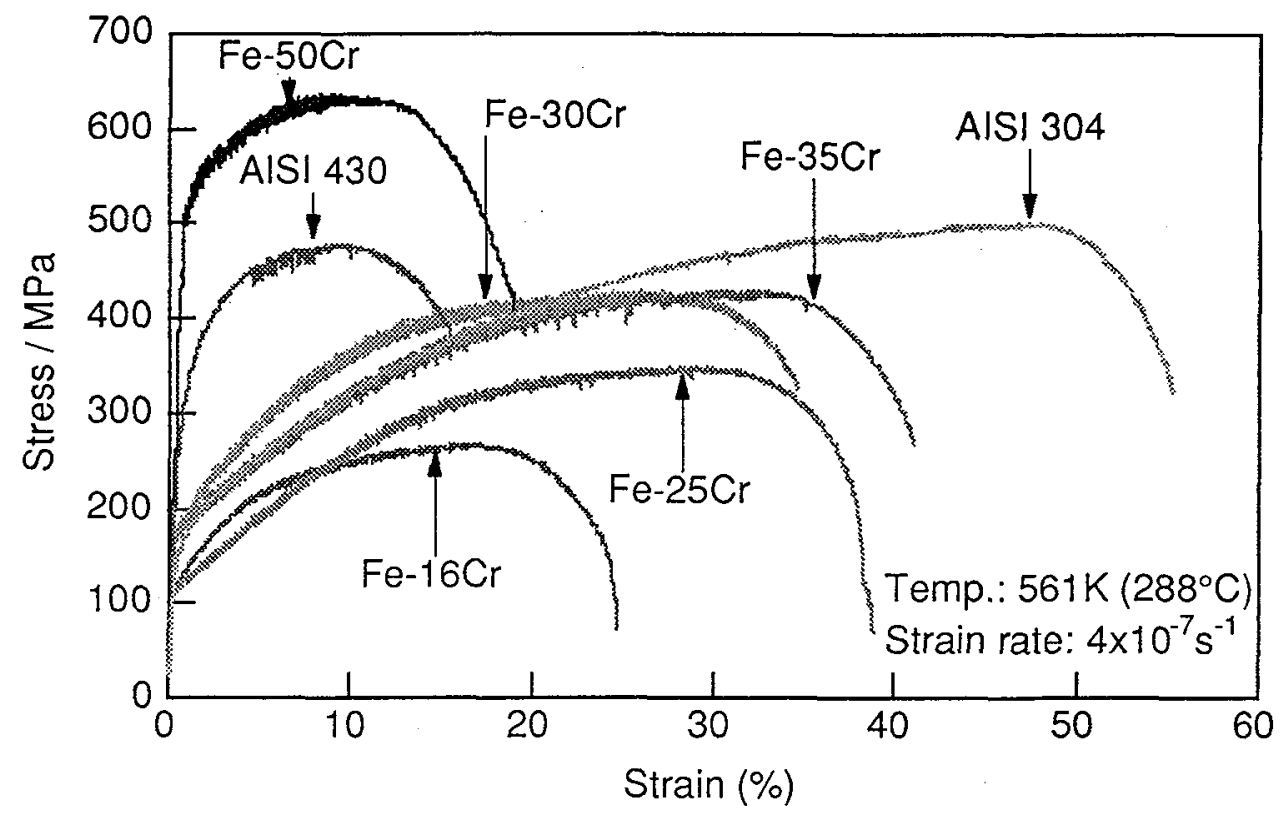

Figure 3 Stress-Strain curves obtaind by tensile test in Ar gas

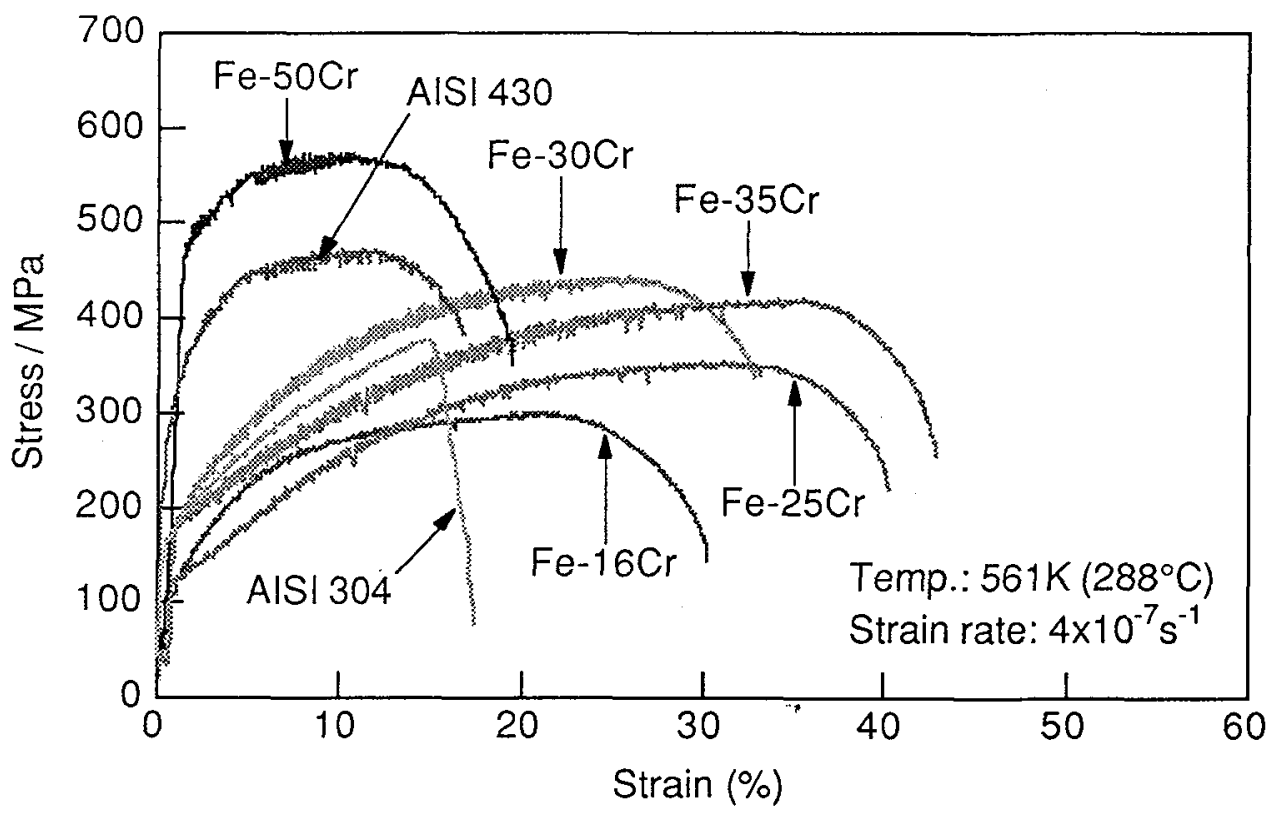

Figure 4 Stress-Strain curves obtaind by SSRT in high purity water containing 8ppm DO (simulated BWR cooling water) 
It is well known that the SCC path of conventional austenitic stainless steels subjected to sensitization treatment propagates intergranularly, due to $\mathrm{Cr}$-depletion and/or segregation of impurities in materials at grain boundaries. In this work, the behaviour of intergranular SCC for the sensitized type304 stainless steel shows good agreement with the above-mentioned aspect [3-7].

In the CERT/SSRT method, SCC sensitivity is evaluated by the increase in SCC fraction on the fractured surface, and by the decrease in ultimate tensile strength and elongation as compared with those of noncorrosive environments [3-5], [9]. It was found from this experimental study, shown in Tables $2 \sim 5$, that there was no difference in either the strength or the elongation of any material with no SCC sensitivity between water and Argon gas environments. On the other hand, both the ultimate tensile strength and total elongation of Type 304 stainless steel can be clearly seen in Figs. 3 and 4.

From the present SCC tests, it was confirmed that high purity $\mathrm{Fe}-\mathrm{Cr}$ alloys have high SCC resistance in simulated Light Water Reactor coolants. It is also well-known that the mechano-chemical effects related to SCC sensitivity are easily accelerated and evaluated by CERT/SSRT methods [9]. From this viewpoint, the high SCC resistance of high purity $\mathrm{Fe}-\mathrm{Cr}$ alloys may mainly be due to formation of a tight, thin oxide film, in which $\mathrm{Cr}$ will be enriched [5,6]. Detailed examination and analysis of the oxide film formed in the simulated LWR water environments will be conducted for high purity $\mathrm{Fe}$-Cr alloys.

\subsection{Fracture Mode}

Every high purity Fe-Cr alloy shows high SCC resistance. The reason for these characteristics may be the formation of $\mathrm{Cr}$-rich oxides, which are formed in corrosive aqueous environments [5, 6]. Only Type 304 stainless steel in the simulated BWR water showed intergranular cracking due to SCC.

The high purity $\mathrm{Fe}-16 \mathrm{Cr},-25 \mathrm{Cr}$, and -35 alloys, and also the intermediate purity $\mathrm{Fe}-30 \mathrm{Cr}$ alloy and Type 430 stainless steel were fractured in ductile mode in a dimple pattern for all corrosive and pure Ar environments. The fracture mode of the high purity $\mathrm{Fe}-50 \mathrm{Cr}$ alloy was a mixture of dimple and cleavagelike transgranular cracking. However, no difference in fracture modes of this material between the corrosive and non-corrosive environments was observed.

\section{CONCLUSION}

High purity $\mathrm{Fe}-\mathrm{Cr}$ alloys showed high SCC resistance in simulated BWR and PWR primary cooling waters. What is especially surprising is that even $\mathrm{Fe}-50 \% \mathrm{Cr}$ alloy shows high $\mathrm{SCC}$ resistance and ductility in these corrosive environments.

\section{Acknowledgement}

The authors would like to express their great appreciation to the Shinko Electric Co., Ltd for the melting of high purity $\mathrm{Fe}-\mathrm{Cr}$ alloys, and also to the Japan Analyst Corporation for the analysis of gaseous impurity elements in high purity Fe-Cr alloys.

\section{References}

[1] "IAEA Technical Committee Meeting on SCC Problems in the Primary Pressure Systems", Palo Alto CA U.S.A., March (1976) pp29-31.

[2] J. R. Weeks; Third Water Reactor Safety Research Information Meeting, Geithersburg MA U.S.A., 1 Oct., (1975).

[3] H. Takaku et al; Corrosion, 35 (1979) 525.

[4] H. Takaku et al; Materials Performance, May (1982) 36.

[5] H. Hirano et al; Corrosion, 39 (1983) 312.

[6] H. Hirano et al; Boshoku Gijitu 34 (1985) 92.

[7] H. Kimura et al; CRIEPI Report, T93001, Nov., 1993.

[8] D. A. Vermilyea et al; Corrosion, 32 (1976) 26.

[9] J. H. Payer et al; ASTM, STP 610, 1976, p.26.

[10] K. Abiko, Proc. of the Workshop II of UHPM'94 (1994) p.522. 